\title{
Impacts of Long Jetties Construction on Shoreline Change at the Western Coast of the Gulf of Thailand
}

\author{
Nathamon Phanomphongphaisarn. ${ }^{1,2, a}$, Chaipant Rukvichai ${ }^{1, b}$, and Butsawan Bidorn ${ }^{1,2, c^{*}}$ \\ 1 Department of Water Resource Engineering, Chulalongkorn University, Bangkok, Thailand \\ 2 WISE Research Unit, Chulalongkorn University, Bangkok, Thailand \\ E-mail: anathamon.p@student.chula.ac.th, bchaipant1@hotmail.com, cbutsawan.p@chula.ac.th \\ (Corresponding author)
}

\begin{abstract}
Pranburi Jetties, a pair of long jetties with a length of $800 \mathrm{~m}$ and $860 \mathrm{~m}$, have been constructed at the Pranburi River inlet, located on the western coast of the Gulf of Thailand since 1999 to stabilize the river mouth. The purposes of this study were to evaluate the responses of shoreline due to the construction of Pranburi Jetties, and the accuracy of the One-Line model (OLM) on predicting the shoreline change due to construction. Based on the shoreline positions retrieving from aerial photographs and satellite imagery during 19672018, the difference in shoreline evolution before and after the construction of the jetties was evaluated using ArcGIS and Digital Shoreline Analysis System. The predicted shorelines using the One-Line model were compared with the image-analyzed shorelines for evaluating the accuracy of the model. The results indicated that the construction of Pranburi Jetties had caused the shoreline accretion at the vicinity of the jetties with the maximum accretion of up to $300 \mathrm{~m}$ in 2018 . The land growth of 16.2 and 9 ha took place at the northern and southern coasts, respectively. The percentage of errors between the predicted and the imageanalyzed shoreline varied from 2 to 13,000 percent with an average of 250 percent. Misprediction in shoreline change using a numerical model caused unnecessary construction of three detached breakwaters at the northern coast of the jetty.
\end{abstract}

Keywords: Coastal structure, shoreline change, sediment characteristics, One-Line model, monitoring.

ENGINEERING JOURNAL Volume 24 Issue 4

Received 8 February 2020

Accepted 24 March 2020

Published 31 July 2020

Online at https://engj.org/

DOI:10.4186/ej.2020.24.4.1 


\section{Introduction}

Coastal structures are constructed along coastal zones for many purposes, such as to control wave and storm surge action and to stabilize a beach. They are also crucial to the establishment of safe and efficient navigation channels and harbor areas [1]. Jetties are common structures built parallel to the inlet channels to channelize an inlet's tidal flow and to reduce the shoaling of the channel by littoral material [2], [3]. The presence of a jetty may alter hydrodynamic regimes, and sediment erosion and/or deposition are consequently created or redistributed. Therefore, the monitoring of jetties' performance in protecting navigation and their impact on their surrounding are technically required. Additionally, projects with new designs or projects designed with the aid of mathematical or hydraulic model studies should be monitored to provide prototype verification of model studies [3].

Most coastal structures receive some monitoring, which may consist of a periodic site visit, accurate surveys, or observation of environment factors [3], [4]. Results from a monitoring program technically provide information on the need for future maintenance and the modification of the project. Nevertheless, the information will be useful for designing future similar structures, so monitoring program is quite common in engineering works worldwide [3]-[10]. In Thailand, many coastal structures have been employed by either public authorities or private sectors during the past half-century. The structures have been used to protect the assets and to reduce the threats from coastal erosion and flooding. However, the monitoring of the coastal project in Thailand has rarely been documented. [11].

The Pranburi Inlet is one of the most important locations for a fishery in Prachuap Khiri Khan Province, which is located in the western part of the Gulf of Thailand (Fig. 1). The Pranburi River mouth had experienced a shoaling of the navigation channel due to river sediment and longshore sediment transport deposited at the river mouth. This shoaling had to render continuous dredging with a cost of about 80,000 USD/year. To stabilize the Pranburi navigation channel. The Pranburi Jetties Project was developed by the Marine Department [12], and the construction of the jetties was completed in 1999.

In the design process of the Pranburi Jetties project, the One-Line numerical model [13], [14], were used to predict the impact of the designed jetties on shoreline change of the Pranburi Coast. The required data for the model simulation mainly consisted of wind and wave characteristics, initial shoreline, bathymetry, sediment transport data, and the dimension of the design structure [13]. However, with the limitations of the One-Line model itself and the quality and quantity of available input data, the predicted shoreline response due to the design jetty may contain uncertainty to some extent.

Up to the present, the One-Line model is still widely used as a standard method for studying the shoreline response due to coastal development projects in Thailand [15]-[17]. The monitoring of the Pranburi Jetties project that has been operated for two decades may contribute some useful information to improve coastal planning and development in Thailand. The objectives of this paper are i) to evaluate the impacts of the Pranburi Jetties on shoreline change and ii) to assess the accuracy of the OneLine model on predicting the shoreline change due to the construction of the Pranburi Jetties. The results of this study can be used to improve not only coastal engineering design, planning and management in the western coast of the Gulf of Thailand but hopefully to be used as a reference for coastal studies worldwide.

\section{Study Area}

In order to monitor the impact of Pranburi Jetties, the study area covered the coastal system from Khao Takiap (in the local language, the meaning of "Khao" is a mountain) to Khao Kalok, Prachuap Khiri Khan Province as shown in Fig. 1. Shoreline orientation was in the northsouth direction from $12^{\circ} 31^{\prime}$ to $12^{\circ} 20^{\prime} \mathrm{N}$ latitude and $99^{\circ}$ $58^{\prime}$ to $100^{\circ} \mathrm{E}$ longitude with a coastline length of about 20 $\mathrm{km}$. The average beach slope along the coast varied between 1:200 and 1:800. [12]. Beach materials were mainly characterized by sand, gravel, and silt with the minority of mollusk, coral and plant contained [18]. Within the Pranburi coastal system, the Pranburi River is the primary fluvial sediment supplied into the Pranburi Coast. Based on the suspended sediment data observed at the hydrological station operated by the Royal Irrigation Department (RID) (Fig. 1), the annual suspended sediment load was about 9,700 metric tons/year [19].

The climate of the study area is dominated by the Northeast (NE) and Southwest (SW) monsoons. The NE monsoon prevails during October-January generating strong wind and waves in a north-northeast direction. In contrast, the SW monsoon, which starts from April to September, induces wind and waves in a south-southwest direction. Significant wave height ranged between 0.1-1.5 $m$ with the wave period of 2-3 seconds [20], [21].

Due to the shoaling problem at the Pranburi River mouth, the Pranburi Jetties project was developed by the Marine Department in 1996 to stabilize the river mouth for navigation purposes [12]. In the process of structural design, shoreline changes due to the proposed jetties were predicted using the One-Line model. Table 1 shows the summary of oceanographic and meteorological data, including the dimension of the jetties, which were used as the input parameters for analyzing shoreline response due to the construction of the Pranburi Jetties. 


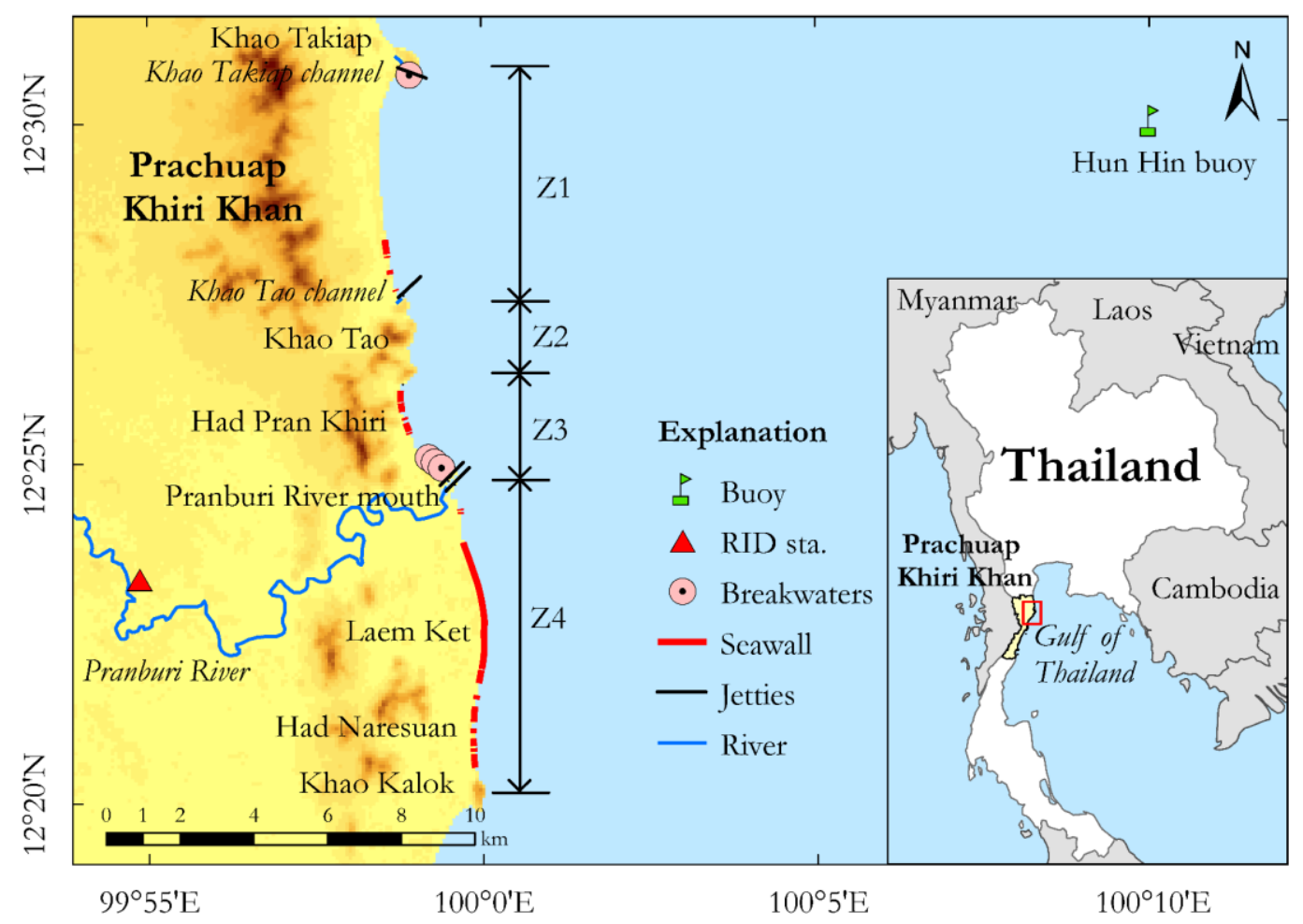

Fig. 1. Location map of the study area and coastal structures along the coast.

The predicted shoreline positions adjacent to the Pranburi River mouth due to the construction of a pair of Pranburi Jetties are depicted in Fig. 2. Results from the shoreline simulation suggested that the construction of the $800 \mathrm{~m}$-long jetties on the north and $860 \mathrm{~m}$-long on the south would cause a maximum shoreline erosion of $-67 \mathrm{~m}$ at the northern coast of the jetty and created a maximum shoreline accumulation of $175 \mathrm{~m}$ on the south of the jetty after 25 years of the construction. Therefore, the construction of three detached breakwaters after the completion of the jetties was recommended to mitigate the shoreline erosion on the northern coast. Additional breakwaters could be added afterward depend on the degree of the jetties impact [12]. In 1999, the Pranburi Jetties were built along with the construction of three $45-\mathrm{m}$ long detached breakwaters at the northern coast of the jetties (Fig. 3b).

\section{Material and Method}

\subsection{Shoreline Data Source and Extraction}

Historical shoreline positions between 1967 and 2018 were extracted from aerial photographs and satellite imagery. Details of the data sources used in this study and their uncertainty are shown in Table 2. In order to eliminate the distortion of the imagery data, all images were geo-referenced and rectified into Universal Transverse Mercator with the World Geodetic System 1984 (WGS1984) using Geographic Information System software (ArcGIS) version 10.4. Then, the natural shoreline positions of fourteen-time periods were delineated using shoreline proxy suggested by Zhang et al. (2014) [22]-[24]. Meanwhile, roads, bridges, dikes, seawalls, and structures were also used to define the coastline of artificial or urbanized coasts [11]. The errors associated with orthorectification are shown in Table 2.

Regarding the tidal range of $1.45 \mathrm{~m}$ and the beach face slope of 1:4 [12], the tidal effect can cause uncertainty of about $5.8 \mathrm{~m}$. Shoreline change pattern prior to the construction of the Pranburi Jetties was studied based on shoreline position extracted from aerial photographs of 1967, 1976, 1983, and 1994. The changes of shoreline positions after the construction of the jetties were derived from aerial photos and satellite imagery taken in 1998, 2009, and 2012-2018.

The rates of shoreline change along the Pranburi Coast were calculated by the Digital Shoreline Analysis System (DSAS) version 4.3, which is an ArcGIS extension [25]. The 210 transects with a spacing of 100 $\mathrm{m}$ were generated perpendicular to Pranburi shoreline (Fig. 3a) for measuring the changes of the shoreline positions between 1967 and 2018. The difference of shoreline positions between two successive shorelines was calculated at each transect and then were used to analyze long- and short-term shoreline changes. The rate of long-term shoreline change for each transect was calculated using Weighted Linear Regression (WLR) method, which has low positional uncertainty values when determining the regression [25]-[29]. However, short-term rates of shoreline change between difference dates at certain points of interest were calculated using End Point Rate (EPR) technique [26], [30], [31]. Moreover, the pattern of coastal area changes between consecutive years was used to estimate sediment transport direction between Khao Kalok and Khao Takiap. 
Table 1. Summary of the parameters used in the coastal engineering study of the Pranburi Jetties project [12].

\begin{tabular}{|c|c|c|}
\hline Designed parameter & \multicolumn{2}{|c|}{ Method / data } \\
\hline 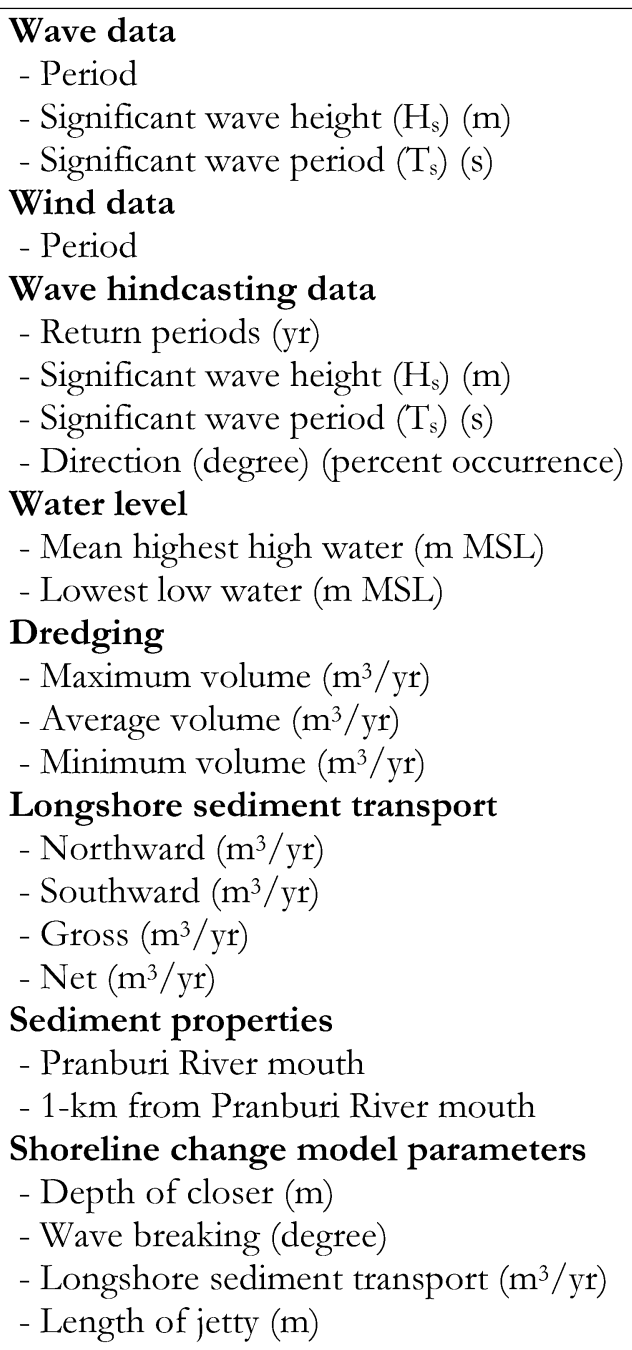 & $\begin{array}{r}46 \\
15 \\
7 \\
\text { Shore Protection } N \\
74 \\
63 \\
13 \\
10,956 \\
\text { Silty clay }( \\
\text { Silty fine-coarse s } \\
\text { One-L } \\
\end{array}$ & $\begin{array}{l}.86 \\
.74 \\
, 025 \\
, 940 \\
000 \\
\text { anual Method (1984) } \\
, 750 \\
, 794 \\
, 544 \\
\text { lorthward) } \\
0.0625 \mathrm{~mm}) \\
\text { nd (0.0078-1.0 mm) } \\
\text { ne model } \\
.0 \\
6^{\circ} \\
, 955 \\
00\end{array}$ \\
\hline Structural design parameters & Jetty & Detached breakwaters \\
\hline $\begin{array}{l}\text { Type } \\
\text { Number of structures } \\
\text { Length of structure (m) } \\
\text { Distance between structures (m) } \\
\text { Structure head (m) }\end{array}$ & $\begin{array}{c}\text { Rubble Mound } \\
2 \\
800 \text { (north), } 860 \text { (south) } \\
220 \\
4.9\end{array}$ & $\begin{array}{c}\text { Rubble Mound } \\
3 \\
60 \\
140-190 \\
4.9 \\
\end{array}$ \\
\hline
\end{tabular}

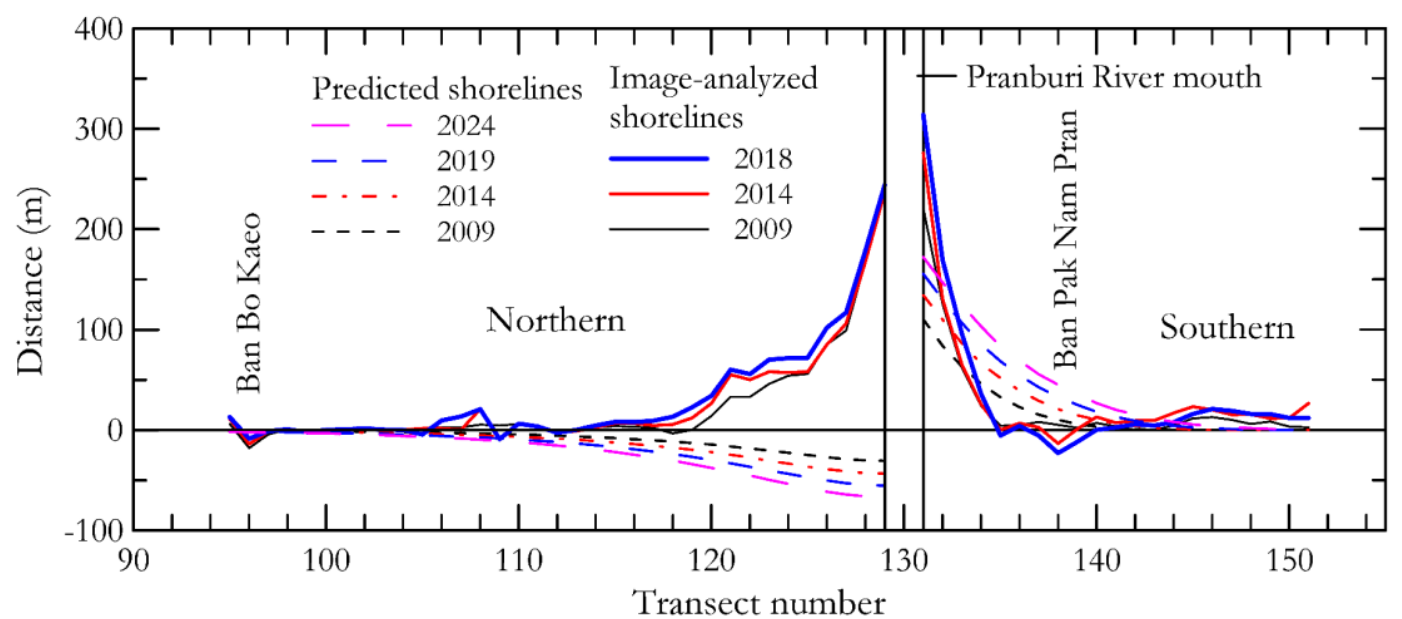

Fig. 2. Comparison between predicted shorelines and the image-analyzed shorelines near the Pranburi River mouth due to the construction of the Pranburi Jetties. 


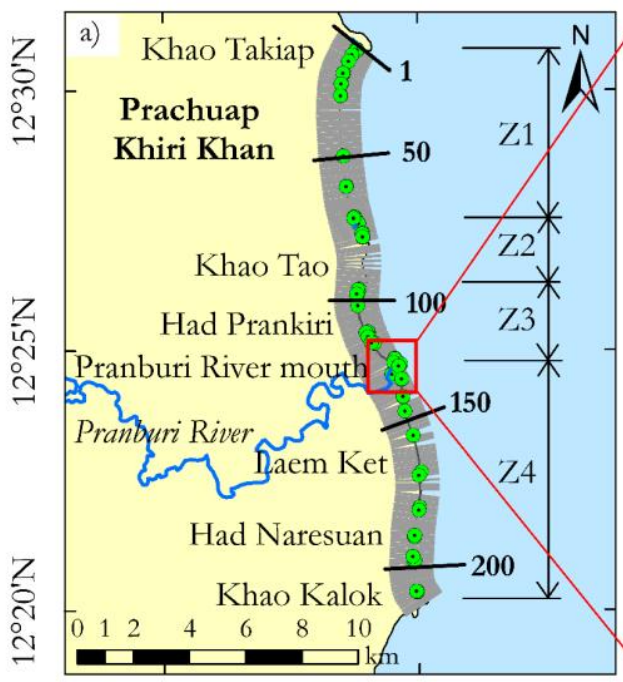

$99^{\circ} 55^{\prime} \mathrm{E}$

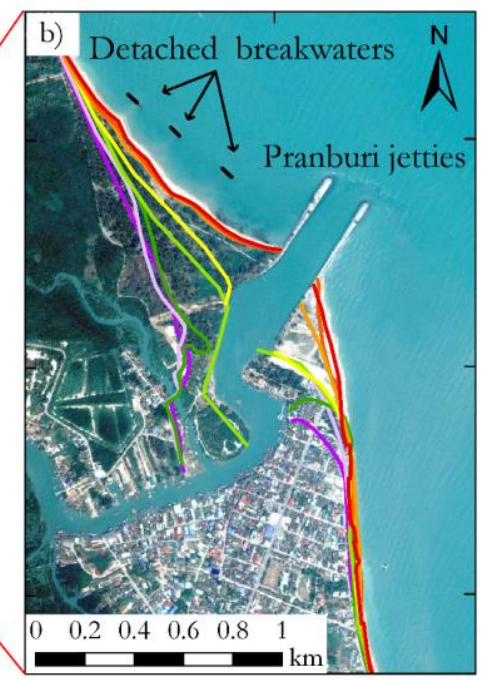

$99^{\circ} 59^{\prime} \mathrm{E}$

$99^{\circ} 60^{\prime} \mathrm{E}$

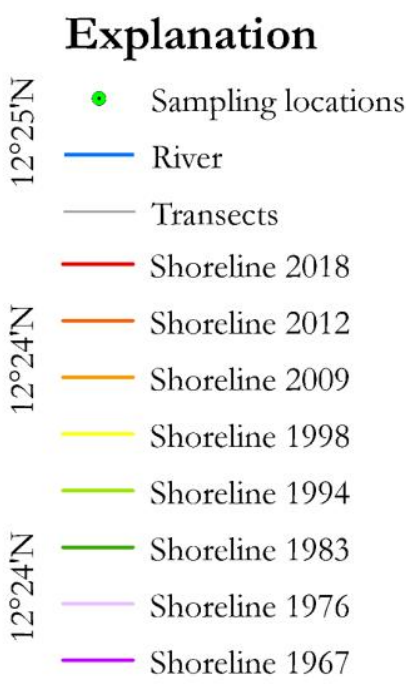

Fig. 3. a) Transects used in shoreline change evaluation and the locations of sediment sampling. b) Historical shoreline changes and coastal engineering structures at the Pranburi River mouth.

Table 2. Summary of the data used for assessing the shoreline change along the Pranburi Coast between 1967 and 2018.

\begin{tabular}{c|c|c|c|c|c}
\hline Year & Data & Source & Scale (m) & $\begin{array}{c}\text { Pixel size } \\
(\mathbf{m})\end{array}$ & $\begin{array}{c}\text { RMSE } \\
(\mathbf{m})\end{array}$ \\
\hline 1967 & Aerial photograph & Royal Thai Survey Department & $1: 50,000$ & 1.2 & 2.95 \\
1976 & Aerial photograph & Royal Thai Survey Department & $1: 15,000$ & 0.4 & 0.84 \\
1983 & Aerial photograph & Royal Thai Survey Department & $1: 15,000$ & 0.4 & 0.82 \\
1994 & Aerial photograph & Royal Thai Survey Department & $1: 50,000$ & 1.25 & 1.32 \\
1998 & Aerial photograph & Royal Thai Survey Department & $1: 50,000$ & 1.11 & 1.01 \\
2009 & Satellite image & Google Earth pro & $1: 700$ & 0.9 & 0.40 \\
2012 & Satellite image & Google Earth pro & $1: 700$ & 1 & 0.51 \\
2013 & Satellite image & Google Earth pro & $1: 700$ & 1.5 & 0.78 \\
2014 & Satellite image & Google Earth pro & $1: 700$ & 0.9 & 0.50 \\
2015 & Orthophotograph & Royal Thai Survey Department & $1: 50,000$ & 1.5 & 0.00 \\
2016 & Satellite image & Google Earth pro & $1: 700$ & 0.9 & 0.50 \\
2017 & Satellite image & Google Earth pro & $1: 700$ & 0.9 & 0.46 \\
2018 & Satellite image & Google Earth pro & $1: 700$ & 1.2 & 0.63 \\
\hline
\end{tabular}

\subsection{Wave and Sediment Data Collection and Analysis \\ Wave data and beach sediment characteristics are} the parameters that play crucial roles in coastal and shoreline change processes. Regarding the Pranburi Jetty design, observed wave and sediment data were limited. In this study, wave information and sediment characteristics of the Pranburi Coast were collected for monitoring the significant factors involving the design of jetty. The 6-hourly observed wave information from Hua Hin Buoy during the period 1997-2000 was obtained from the report on "Hydrographic and marine structures studies" under the Survey and Detailed Design on Southern Short-cut motorway Project [20]. Hua Hin oceanographic buoy operated by the GeoInformatics and Space Technology Development Agency (Public Organization) (GISTDA) was deployed at approximately $12^{\circ} 30^{\prime} \mathrm{N} 100^{\circ} 10^{\prime} \mathrm{E}$ (Fig. 3a) with the water depth of about $18 \mathrm{~m}$. However, only the height and period of waves were measured due to the limitation of the wave sensor.

To study sediment characteristics of the Pranburi Coast, three field surveys were carried out in June and September 2018 (during the SW monsoon), and January 2019 (during the NE monsoon) to collect beach materials along the Pranburi Coast (Fig. 3a). Beach materials with a 10 - to 20 -cm deep were collected in the surf zone. Forty-six samples were collected during the SW monsoon, while twenty-five samples were collected during the NE monsoon. The ASTM method [32], a standard test for particle-size analysis of soil, were used to analyze the particle size of sediment samples. The types of beach material along the coast were classified using the Wentworth scale [33], [34]. The diameter of the sediment particle was converted to the phi unit using Eq. (1). Then, the sediment characteristics such as 
median $\left(\mathrm{d}_{50}\right)$, mean $\left(\mathrm{M}_{\mathrm{z}}\right)$ and sorting $\left(\sigma_{1}\right)$ defined by Folk and Ward (1957) [35] was calculated using Eq. (2)(3). The $d_{50}$ was grain size represents a particle size at 50 percentiles.

$$
\phi=-\log _{2} d
$$

where $\phi$ was the particle diameter in the phi unit, and $\mathrm{d}$ was the diameter of a particle in $\mathrm{mm}$.

$$
\begin{aligned}
& \mathrm{M}_{\mathrm{z}}=\frac{\phi 16+\phi 50+\phi 84}{3} \\
& \sigma_{1}=\frac{\phi 84-\phi 16}{4}+\frac{\phi 95-\phi 5}{6.6}
\end{aligned}
$$

where $\phi 5, \phi 16, \phi 50, \phi 84$, and $\phi 95$ represented the particle diameter at 5, 16,50,84, and 95 percent in phi unit, respectively.

\subsection{Evaluation of One-Line Model Performance}

One-Line model is commonly used to predict the shape of shoreline in response to the coastal development projects in Thailand, including the Pranburi Jetties project. In this study, the performance of the One-Line model on estimating the shoreline response due to the jetties construction was assessed by comparing the predicted shoreline and the shorelines analyzed from the imagery data after the construction. The predicted shoreline positions in 2009, 2014, and 2018 were reported by Marine Department in 1996 [12], while the image-analyzed shorelines corresponding to the predicted dates were extracted from satellite images, as shown in Fig. 2. The absolute errors on prediction were calculated using Eq. (4).

$$
\% \text { error }=\frac{\left|S_{a}-S_{p}\right|}{S_{a}} \times 100 \%
$$

where $S_{a}$ was an image-analyzed shoreline distance from the original baseline, and $S_{p}$ was a predicted shoreline distance from the original baseline.

\section{Results}

\subsection{Historical of Shoreline Change}

The study area was divided into four littoral zones (Zones 1, 2, 3, and 4 in Fig. 1) to assess the shoreline change along the Pranburi Coast in detail. Zone 1 (Z1), the northmost zone, had a $7.3 \mathrm{~km}$ long started from Khao Takiap to Khao Tao (transects 1-73). Zone 2 (Z2), the shortest coastline with a length of $1 \mathrm{~km}$, consisted of two pocket beaches lied between transects 77 and 79 and between 85 and 89. Zone 3 (Z3) covered Had Pran Khiri (3.4 km long), which extended from Kho Tao to the Pranburi River mouth (transects 95-129). Zone 4 (Z4) was the southmost littoral zone lied between Laem Ket and Had Naresuan (transects 130-210). The length of the $\mathrm{Z} 4$ coastline was $8 \mathrm{~km}$.

The results from shoreline change analysis for preand post-construction of the jetties are illustrated and summarized in Fig. 4 and Table 3, respectively. The positive value indicates shoreline accretion and, the negative value denotes shoreline recession. Figure 4 depicted the evolution of shoreline movement and average shoreline change rates for pre- and postconstruction of the jetties. The responses of the shoreline along the study area due to the construction are discussed in detail as followed:

\subsubsection{Shoreline changed during the period 1967-1994} (pre-Pranburi Jetties construction)

Before the construction of the Pranburi Jetties (1967-1994), about 60 percent of the Pranburi Coast had advanced seaward with a total land growth of 30.6 ha (1.1 ha/yr). Regarding Table 3, the significant shoreline accretion was found at Z3 (16 ha or $0.6 \mathrm{ha} / \mathrm{yr}$ ) and Z4 (9 ha or $0.33 \mathrm{ha} / \mathrm{yr}$ ), where the Pranburi River mouth is located. The maximum shoreline advance of $216 \mathrm{~m}$ occurred at the northern coast of the river mouth (Z3) due to the formation of sand spit (Fig. 3b). The Z1 and $\mathrm{Z} 2$ coastlines were relatively stable as their average shoreline accumulation rates were less than $0.5 \mathrm{~m} / \mathrm{yr}$. The remaining of the Pranburi coastline experienced shoreline recession with an average rate at each zone of less than $-1.0 \mathrm{~m} / \mathrm{yr}$ (Table 3). Total land loss during this period was about 9.1 ha $(-0.34 \mathrm{ha} / \mathrm{yr})$. However, the erosion at Z1, Z2, and Z3 was insignificant as the shoreline retreat rate in each zone was less than -0.2 $\mathrm{m} / \mathrm{yr}$. The significant shoreline retreat occurred mainly in Z4 (Laem Ket: Fig. 4a). The average and maximum rates of shoreline retreat in Z4 were -0.5 and $-1.0 \mathrm{~m} / \mathrm{yr}$, respectively. The land loss along the Z4 was 7.5 ha $(-0.3$ $\mathrm{ha} / \mathrm{yr})$, accounting for $82 \%$ of the total land losses of the Pranburi Coast. The maximum shoreline recession of $-27 \mathrm{~m}$ was found at Laem Ket (transect 167). Results from shoreline analysis of each littoral zone (Table 3) indicate that the Pranburi Coast were prograding seaward with the net change in the coastal area of 21.5 ha before the construction of the Pranburi Jetties.

\subsubsection{Shoreline change during the period 1998-2018} (post-Pranburi Jetties construction)

Based on the analysis of shoreline positions between 1998 and 2018 (20 years after the Pranburi Jetties construction) in Table 3 , the percentage of shoreline recession along the Pranburi Coast reduced from 40 to 31 percent after the construction. Therefore, the percentage of shoreline accretion increased. The average rate of land growth also slightly raised from 1.13 to $1.3 \mathrm{ha} / \mathrm{yr}$ resulting in the total land accretion of about 27 ha. Moreover, the average rate of land loss decreased from -0.3 to $-0.1 \mathrm{ha} / \mathrm{yr}$ resulting in land loss of about 2.4 ha.

After the construction of the jetties, the erosional shoreline in the Z1 littoral zone increased from 29 to 42 percent of 73 transects. The rate of land loss also increased from 0.02 to $0.05 \mathrm{ha} / \mathrm{yr}$, while the rate of land growth remained unchanged $(0.16 \mathrm{ha} / \mathrm{yr})$. The percentage of land loss in this littoral zone increased to 
26 percent. The land loss consequently increased by 1.1 ha, even though the rate of shoreline erosion was similar to that during the pre-construction. Meanwhile, the mean shoreline accretion rate increased to $0.7 \mathrm{~m} / \mathrm{yr}$ resulting in land accretion of $3.2 \mathrm{ha}$. The maximum land growth rate also raised from 0.9 to $7.1 \mathrm{~m} / \mathrm{yr}$, and the maximum shoreline advance of $142 \mathrm{~m}$ was found at Ban Khao Tao (Fig. 4a).
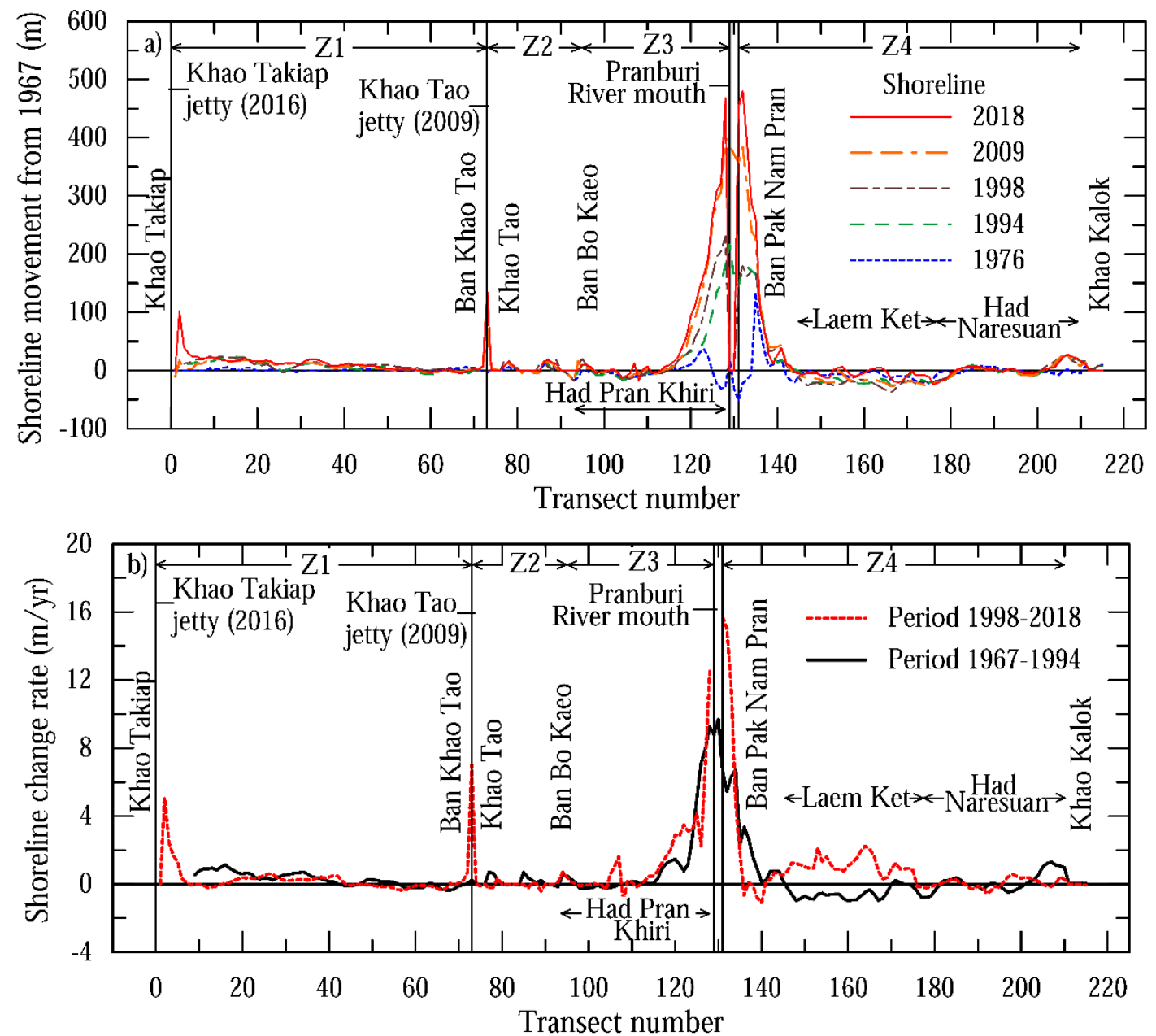

Fig. 4. a) Evolution of shoreline positions compared to the shoreline in 1967. b) Rates of shoreline change before and after the Pranburi Jetties construction.

Table 3. Results of shoreline change analysis for pre- and post-construction of the Pranburi Jetties project.

\begin{tabular}{|c|c|c|c|c|c|c|c|c|c|c|}
\hline \multirow{2}{*}{ Data } & \multicolumn{5}{|c|}{ Pre-construction (1967-1994) } & \multicolumn{5}{|c|}{ Post-construction (1998-2018) } \\
\hline & Z1 & $\mathbf{Z} 2$ & $\mathrm{Z3}$ & $\mathbf{Z} 4$ & Total & $\mathrm{Z1}$ & $\mathbf{Z} 2$ & $\mathrm{Z3}$ & $\mathrm{Z} 4$ & Total \\
\hline Number of transects & 73 & 8 & 34 & 80 & 195 & 73 & 8 & 34 & 80 & 195 \\
\hline Maximum shoreline retreat (m) & -11 & -6 & -15 & -27 & -27 & -8 & -11 & -9 & -23 & -23 \\
\hline Maximum shoreline advance (m) & 24 & 17 & 216 & 181 & 216 & 142 & 10 & 250 & 300 & 300 \\
\hline Land loss area (ha) & 0.5 & 0.03 & 1.1 & 7.5 & 9.1 & 1.1 & 0.2 & 0.3 & 0.8 & 2.4 \\
\hline Land growth area (ha) & 4.4 & 1.0 & 16.2 & 9.0 & 30.6 & 3.2 & 0.5 & 9.6 & 13.6 & 26.9 \\
\hline Area recession (percent) & 11 & 3 & 6 & 45 & 23 & 26 & 29 & 3 & 6 & 8 \\
\hline Area accretion (percent) & 89 & 97 & 94 & 55 & 77 & 74 & 71 & 97 & 94 & 92 \\
\hline Shoreline recession (percent) & 29 & 25 & 29 & 54 & 40 & 42 & 56 & 26 & 25 & 31 \\
\hline Shoreline accretion (percent) & 71 & 75 & 71 & 46 & 60 & 58 & 44 & 74 & 75 & 69 \\
\hline Shoreline change rate $(\mathrm{m} / \mathrm{yr})$ & & & & & & & & & & \\
\hline - Mean shoreline change rate & 0.3 & 0.3 & 1.2 & 0.4 & 0.5 & 0.3 & -0.1 & 1.5 & 0.9 & 0.7 \\
\hline - Maximum retreat rate & -0.4 & -0.2 & -0.6 & -1.0 & -1.0 & -0.4 & -0.6 & -0.5 & -1.2 & -1.2 \\
\hline - Mean retreat rate & -0.2 & -0.1 & -0.2 & -0.5 & -0.4 & -0.1 & -0.2 & -0.2 & -0.3 & -0.2 \\
\hline - Maximum accretion rate & 0.9 & 0.6 & 8.0 & 6.7 & 8.0 & 7.1 & 0.5 & 12.5 & 15.0 & 15.0 \\
\hline - Mean accretion rate & 0.4 & 0.5 & 2.0 & 1.3 & 1.0 & 0.7 & 0.2 & 2.1 & 1.2 & 1.2 \\
\hline
\end{tabular}

In Z2 (8 transects), the percentage of shoreline retreat significantly increased to 56 percent of the coastline. The land loss was insignificant compared to those in other sub-littoral zones because of the low rate 
of shoreline retreat $(-0.2 \mathrm{~m} / \mathrm{yr})$. The shoreline accumulation in $\mathrm{Z} 2$ after the jetties construction was also insignificant $(0.2 \mathrm{~m} / \mathrm{yr})$ compared to the total land growth of the study area. The maximum shoreline advance was only $10 \mathrm{~m}$ over the past 20 years.

Of the 34 transects along with the Z3 littoral cell, about 26 percent was eroding after the construction of jetties at the northmost of the littoral zone with a similar rate to the pre-construction shoreline recession rate ($0.2 \mathrm{~m} / \mathrm{yr}$ ). The remaining shoreline extended seaward, and the mean rate of shoreline accumulation was about $2.0 \mathrm{~m} / \mathrm{yr}$. Even though the maximum shoreline advance of $250 \mathrm{~m}$ occurred at the Pranburi River mouth due to the construction of the jetties, but the rate of land accretion in this littoral zone reduced from $0.6 \mathrm{ha} / \mathrm{yr}$ to $0.5 \mathrm{ha} / \mathrm{yr}$.

In the Z4 littoral zone with 80 transects, the jetties construction caused significant effects to shoreline change patterns (Fig. 4b). The percentage of accumulating shoreline increased from 46 to 75 percent. The mean shoreline accretion rate slightly decreased from 1.3 to $1.2 \mathrm{~m} / \mathrm{yr}$, but it contributed a significant land growth of 13.6 ha $(50$ percent of total land accretion after the jetties construction). The maximum shoreline advance of $300 \mathrm{~m}$ occurred at the southern coast of the jetty (Fig. 4a). Land growth was found along the Laem Ket and Had Naresuan (Fig. 4a), which were erosional zones before construction of the jetties. Consequently, the mean shoreline recession in $\mathrm{Z} 4$ also reduced from -0.5 to $-0.3 \mathrm{~m} / \mathrm{yr}$.

\subsection{Wave Characteristics and Beach Material Properties}
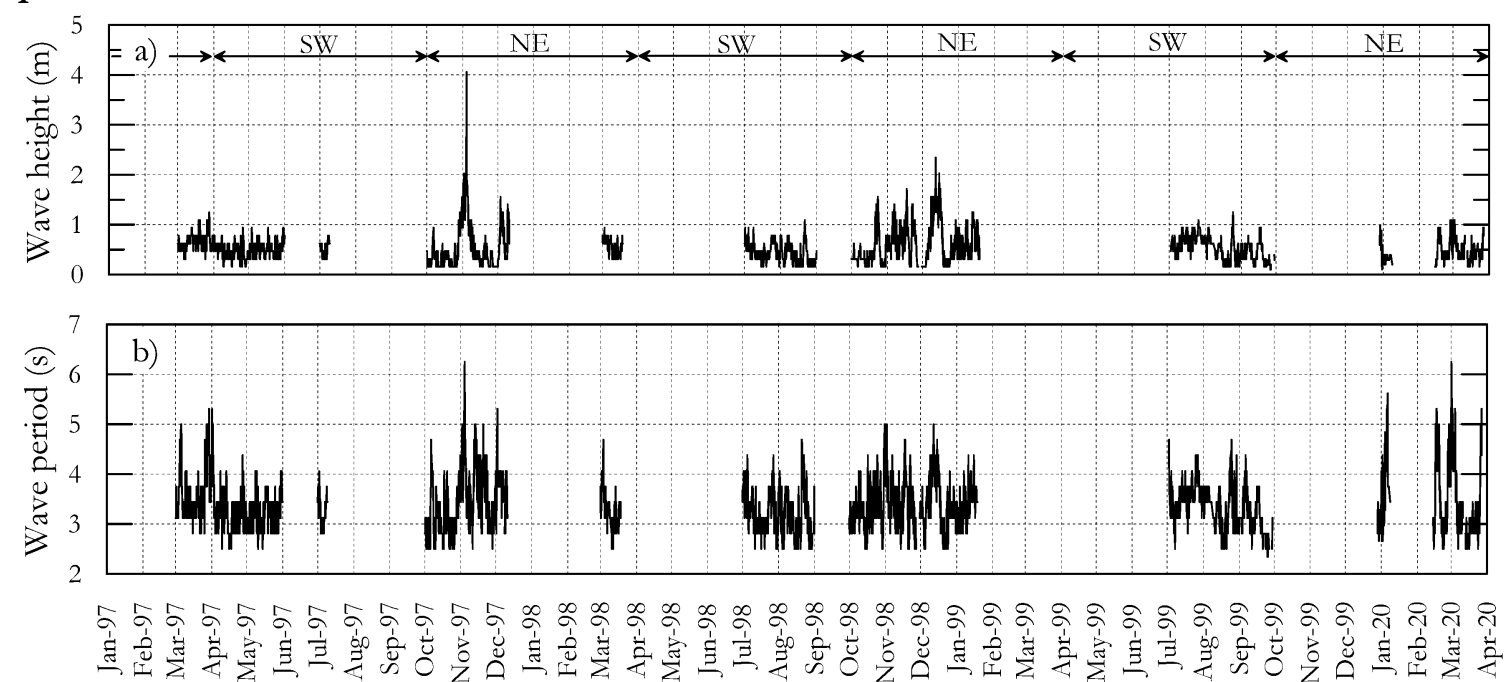

Month

Fig. 5. Time-series of wave data at Hua Hin oceanographic buoy during 1997-2000. a) wave height and b) wave period.
Hin Buoy, time series of wave height and wave period between 1997 and 2000 were plotted as shown in Fig. 5 a) and b), respectively. However, the wave record contained about 50 percent of missing data due to the malfunction of the wave sensor and signal transmission losses during severe climate conditions. According to the wave data, approximately 51 percent of the valid data was recorded during the SW monsoon (AprilSeptember), while the remainder was measured during the NE monsoon (October-March).

Regarding the statistical analysis of wave data, the occurrence of the wave height and wave period during the NE and SW monsoons are presented in Tables 4 and 5 , respectively. The primary statistic parameters of the available wave information were summarized in Table 6. Based on Table 5, more than 90 percent of the valid wave height was less than 1 meter with the wave period of 2-5 seconds; almost 70 percent ranged between 0.25 and $0.75 \mathrm{~m}$. The wave height occurring during the NE monsoon was generally higher than that during the SW monsoon. The average wave height measured during the NE and SW monsoons was 0.57 and $0.47 \mathrm{~m}$, respectively (Table 6 ). The maximum wave height of $4.06 \mathrm{~m}$ was observed in November 1997 as a result of the tropical storm "Linda" event, while the maximum wave height observed during the SW and transitional monsoons were only $1.25 \mathrm{~m}$. For the wave period, the waves generated during the NE monsoon had a slightly longer wave period than those produced by the SW monsoons. 
Table 4. Distribution of wave height observed at Hua Hin buoy during 1997-2000.

\begin{tabular}{c|cccccccccc}
\hline \multirow{2}{*}{ Monsoon } & \multicolumn{8}{|c}{ Wave height (m) } & \multirow{2}{*}{ Total } \\
& $0-0.25$ & $0.25-0.5$ & $0.5-0.75$ & $0.75-1.0$ & $1.0-1.25$ & $1.25-1.5$ & $1.5-1.75$ & $1.75-2.0$ & $>2.0$ & \\
\hline Northeast & 159 & 476 & 197 & 198 & 80 & 17 & 21 & 3 & 6 & 1,157 \\
(Oct-Mar) & $(6.7 \%)$ & $(20 \%)$ & $(8.3 \%)$ & $(8.3 \%)$ & $(3.4 \%)$ & $(0.7 \%)$ & $(0.9 \%)$ & $(0.1 \%)$ & $(0.3 \%)$ & $(48.6 \%)$ \\
Southwest & 149 & 668 & 250 & 150 & 6 & - & - & - & - & 1,223 \\
(Apr-Sep) & $(6.3 \%)$ & $(28.1 \%)$ & $(10.5 \%)$ & $(6.3 \%)$ & $(0.2 \%)$ & & & & & $(51.4 \%)$ \\
\hline \multirow{2}{*}{ Total } & 308 & 1,144 & 447 & 348 & 86 & 17 & 21 & 3 & 6 & 2,380 \\
& $(12.9 \%)$ & $(48.1 \%)$ & $(18.8 \%)$ & $(14.6 \%)$ & $(3.6 \%)$ & $(0.7 \%)$ & $(0.9 \%)$ & $(0.1 \%)$ & $(0.3 \%)$ & $(100 \%)$ \\
\hline
\end{tabular}

Table 5. Distribution of wave period observed at Hua Hin buoy during 1997-2000.

\begin{tabular}{c|cccccccccc}
\hline \multirow{2}{*}{ Monsoon } & \multicolumn{7}{|c}{ Wave period (s) } & & & \multirow{2}{*}{ Total } \\
& $0-1$ & $1-2$ & $2-3$ & $3-4$ & $4-5$ & $5-6$ & $6-7$ & $7-8$ & $>8$ & \\
\hline Northcast & - & - & 237 & 683 & 222 & 13 & 2 & - & - & 1,157 \\
(Oct-Mar) & & & $(10 \%)$ & $(28.7 \%)$ & $(9.3 \%)$ & $(0.5 \%)$ & $(0.1 \%)$ & & - & $(48.6 \%)$ \\
Southwest & - & - & 316 & 821 & 84 & 2 & - & - & - & 1,223 \\
$(\Lambda$ pr-Sep) & & & $(13.2 \%)$ & $(34.5 \%)$ & $(3.6 \%)$ & $(0.1)$ & & & $(51.4 \%)$ \\
\hline \multirow{2}{*}{ Total } & - & - & 553 & 1,504 & 306 & 15 & 2 & - & - & 2,380 \\
& & & $(23.2 \%)$ & $(63.2 \%)$ & $(12.9 \%)$ & $(0.6 \%)$ & $(0.1 \%)$ & & $(100 \%)$ \\
\hline
\end{tabular}

Table 6. Summary of wave statistics observed at Hua Hin buoy during 1997-2000.

\begin{tabular}{cc|cc}
\hline \multicolumn{2}{c|}{$\begin{array}{c}\text { Wave } \\
\text { characteristics }\end{array}$} & $\begin{array}{c}\text { Northeast } \\
\text { Monsoon }\end{array}$ & $\begin{array}{c}\text { Southwest } \\
\text { Monsoon }\end{array}$ \\
\hline Wave & Max & 4.06 & 1.25 \\
height & Mean & 0.57 & 0.47 \\
(m) & Min & 0.10 & 0.10 \\
& SD & 0.37 & 0.20 \\
\hline Wave & Max & 6.25 & 5.31 \\
period & Mean & 3.47 & 3.27 \\
(s) & Min & 2.50 & 2.34 \\
& SD & 0.62 & 0.44 \\
\hline
\end{tabular}

For the sediment characteristic of the Pranburi Coast, sediment properties analyzed from 71 sediment samples in the study area (Fig. 3a) are plotted in Fig. 6, and the sediment properties in each littoral zone are summarized in Table 7 . The results from sediment analysis indicated that the beach of the Z1 littoral cell was mainly characterized by fine sand (Fig. 6a) ranged between $0.13-0.21 \mathrm{~mm}$ with an average $\mathrm{d}_{50}$ of less than $0.2 \mathrm{~mm}$ (Table 7). The grain size of the beach materials was relatively uniform throughout the Z1 cell and seasonal independent. Beach materials along the Z2 were categorized as fine to medium sand $\left(\mathrm{d}_{50} \approx 0.2-0.5\right.$ $\mathrm{mm}$ ) and poorly sorted during the SW monsoon. In comparison, the sediment grain size increased to 0.66$0.77 \mathrm{~mm}$ (coarse sand) with the moderately well sorting during the NE monsoon. The characteristics of beach materials at Z3 and Z4 were relatively similar in size and dispersion (Table 7) but in the opposite direction (Fig. 5). The average $d_{50}$ of the beach material during the SW monsoon at Z3 and Z4 was 0.29 and $0.35 \mathrm{~mm}$, respectively. During NE monsoon, the grain size of the beach materials became coarser sand with the $d_{50}$ of $0.47 \mathrm{~mm}$ for Z3 and $0.44 \mathrm{~mm}$ for Z4 (Fig. 6)
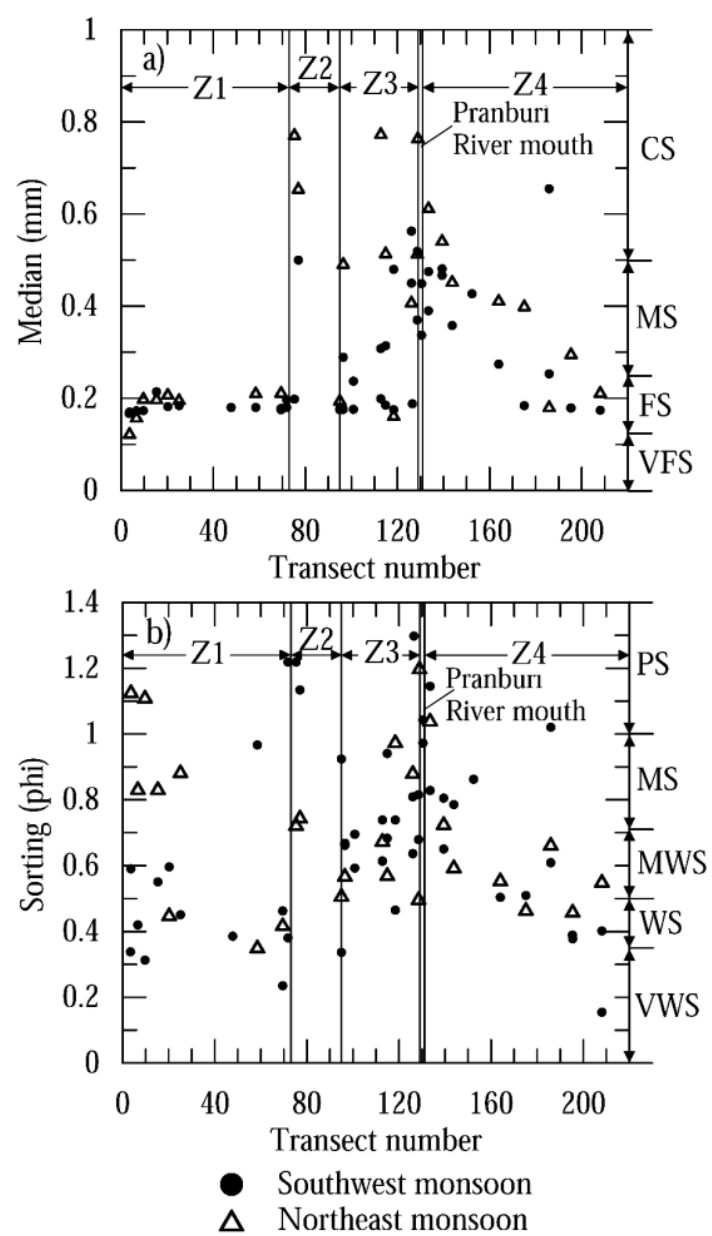

Fig. 6. a) Median grain size of beach material found along the Pranburi Coast during the SW and NE monsoon. (VFS = very fine sand, FS= fine sand, MS= medium sand, $C S=$ coarse sand) and b) Beach sediment sort $($ VWS $=$ very well sorted, WS $=$ well-sorted, MWS $=$ moderately well sorted, MS= moderately sorted, PS= poorly sorted). 
Table 7. Properties of beach materials along the Pranburi Coast during the SW and NE monsoons.

\begin{tabular}{|c|c|c|c|c|c|c|c|c|c|}
\hline \multirow{2}{*}{\multicolumn{2}{|c|}{ Properties }} & \multicolumn{2}{|c|}{ Z1 } & \multicolumn{2}{|c|}{ Z2 } & \multicolumn{2}{|c|}{ Z3 } & \multicolumn{2}{|c|}{$\mathrm{Z} 4$} \\
\hline & & SW & $\mathrm{NE}$ & SW & $\mathrm{NE}$ & SW & $\mathrm{NE}$ & SW & $\mathrm{NE}$ \\
\hline \multirow{4}{*}{$\begin{array}{l}\text { Median } \\
(\mathrm{mm})\end{array}$} & Max & 0.21 & 0.21 & 0.50 & 0.77 & 0.56 & 0.78 & 0.66 & 0.77 \\
\hline & Mean & 0.18 & 0.19 & 0.35 & 0.72 & 0.29 & 0.47 & 0.35 & 0.44 \\
\hline & Min & 0.17 & 0.13 & 0.20 & 0.66 & 0.18 & 0.16 & 0.17 & 0.18 \\
\hline & SD & 0.01 & 0.03 & 0.21 & 0.08 & 0.13 & 0.22 & 0.15 & 0.18 \\
\hline \multirow{4}{*}{$\begin{array}{l}\text { Mean } \\
(\mathrm{mm})\end{array}$} & Max & 0.26 & 0.22 & 0.42 & 0.72 & 0.54 & 0.76 & 0.62 & 0.81 \\
\hline & Mean & 0.19 & 0.19 & 0.37 & 0.67 & 0.27 & 0.42 & 0.31 & 0.41 \\
\hline & Min & 0.16 & 0.14 & 0.33 & 0.62 & 0.18 & 0.16 & 0.17 & 0.17 \\
\hline & SD & 0.03 & 0.03 & 0.06 & 0.07 & 0.10 & 0.21 & 0.13 & 0.21 \\
\hline \multirow{4}{*}{$\begin{array}{c}\text { Sorting } \\
\text { (phi) }\end{array}$} & Max & 0.97 & 1.13 & 1.22 & 0.75 & 1.30 & 0.98 & 1.15 & 1.20 \\
\hline & Mean & 0.48 & 0.75 & 1.18 & 0.74 & 0.73 & 0.74 & 0.66 & 0.68 \\
\hline & Min & 0.24 & 0.36 & 1.13 & 0.73 & 0.47 & 0.57 & 0.15 & 0.30 \\
\hline & SD & 0.20 & 0.31 & 0.06 & 0.02 & 0.22 & 0.08 & 0.26 & 0.25 \\
\hline
\end{tabular}

\subsection{Errors in Shoreline Change Prediction}

The positions of the image-analyzed shorelines (transects 95-151) and the predicted shorelines due to the construction of the Pranburi Jetties using the OneLine Model [12] were plotted, as shown in Fig. 2. The transects 95-151 were divided into two portions to evaluate the effectiveness of shoreline prediction at the northern coast (transects 95-129) and southern (transects 131-151) of the jetty. The comparison of predicted and image-analyzed shoreline changes between transects 95-151 are summarized in Table 8 .

Regarding Fig. 2, the results from the One-Line model suggested that the construction of the jetties would cause shoreline recession at the northern coast and shoreline accretion at the southern coast. On the north coast, the model simulation for 2009, showed that the shoreline retreat would start at the transect 95 and reach the maximum recession of $-31 \mathrm{~m}$ at transect 129 adjacent to the jetty. Then, the shoreline recession would increase overtimes with the maximum shoreline retreat adjacent to the jetties of $-43,-49$, and $-67 \mathrm{~m}$ in 2014, 2018, and 2024, respectively. Consequently, the shoreline recession would cause land loss of 3.3 ha in 2009 to 8 ha in 2024. In contrast, the results from model simulation indicated that the accretion of the shoreline would take place on the southern coast between the transects 131 (adjacent to the south jetty) and 151. The maximum shoreline accretion was estimated at $110 \mathrm{~m}$ in 2009 and would increase over time up to $172 \mathrm{~m}$ in 2024. they were resulting the land growth of 3.4 ha in 2009 to 8.5 ha in 2024 (Table 8).

However, the analysis of image-analyzed shoreline changes after the jetties construction reveals that shoreline accretion occurred on both the northern and southern coast of the jetties (Fig. 2). On the north shore of the jetties, the shoreline retreat was found at Ban Bo Kaeo (transect 96) with the maximum shoreline retreat of $-18 \mathrm{~m}$ in 2009, but the shoreline then moved seaward, and the maximum shoreline retreat was $-9 \mathrm{~m}$ in 2018 . The remaining shore mainly had a shoreline deposition trend. The maximum shoreline accretion of up to 250 $\mathrm{m}$ took place adjacent to the north jetty in 2018 instead of the maximum retreat of $-49 \mathrm{~m}$ as predicted. With the average shoreline movement of $30 \mathrm{~m}$ in 2009 , of $27 \mathrm{~m}$ in 2014, and $32 \mathrm{~m}$ in 2018, the shoreline growths were 7.5, 8.5, and 10 ha in 2009, 2014, and 2018, respectively.

Based on the comparison of the image-analyzed and predicted shorelines (Table 8), the maximum absolute error of shoreline prediction ranged from 267 $\mathrm{m}$ (in 2009) to $300 \mathrm{~m}$ (in 2018) at the northern coast. Meanwhile, the maximum absolute errors of prediction for the southern coast varied from $111 \mathrm{~m}$ (in 2009) and $160 \mathrm{~m}$ (in 2018). The average uncertainties for the shoreline prediction were $35-44 \mathrm{~m}$ for the northern coast and $15-26 \mathrm{~m}$ for the southern coast. The percentage of absolute errors of the shoreline prediction are summarized in Table 9. It was found that, with the model input parameters in Table 1, the estimation of area changes on the southern coast agreed with the change of area analyzed from imagery data in terms of shoreline response pattern (land growth). The absolute error of the prediction varied between 2-655 percent. In contrast, the prediction of area changes (land loss) on the northern coast was opposite to the image-analyzed area changes, which predominated by the land growth (Table 9). The uncertainty of the predictions ranged from 6 to 13,000 percent. 
Table 8. Comparison of shoreline change between the image-analyzed and predicted shorelines along transects 95-151.

\begin{tabular}{|c|c|c|c|c|c|c|c|c|}
\hline \multirow{2}{*}{ Data } & \multicolumn{2}{|c|}{2009} & \multicolumn{2}{|c|}{2014} & \multicolumn{2}{|c|}{2018} & \multicolumn{2}{|c|}{2024} \\
\hline & $* \mathbf{N}$ & $* * \mathrm{~S}$ & $\mathbf{N}$ & $\mathrm{S}$ & $\mathbf{N}$ & $\mathbf{S}$ & $\mathbf{N}$ & $\mathrm{S}$ \\
\hline Number of transects & 35 & 20 & 35 & 20 & 35 & 20 & 35 & 20 \\
\hline Number of inverted shoreline direction & 30 & 0 & 29 & 1 & 29 & 4 & - & - \\
\hline \multicolumn{9}{|l|}{ Predicted area change (ha) } \\
\hline Recession area & 3.3 & 0 & 4.8 & 0 & 6.5 & 0 & 8 & 0 \\
\hline Accretion area & 0 & 3.4 & 0 & 5.1 & 0 & 6.8 & 0 & 8.5 \\
\hline Total & 3.3 & 3.4 & 4.8 & 5.1 & 6.5 & 6.8 & 8 & 8.5 \\
\hline \multicolumn{9}{|l|}{ Actual area change (ha) } \\
\hline Recession area & 0.3 & 0 & 0.2 & 0.1 & 0.2 & 0.4 & - & - \\
\hline Accretion area & 7.5 & 4.2 & 8.5 & 5.4 & 10.0 & 5.9 & - & - \\
\hline Total & 7.7 & 4.2 & 8.7 & 5.5 & 10.2 & 6.3 & 0 & 0 \\
\hline \multicolumn{9}{|l|}{ Predicted shoreline change $(\mathrm{m})$} \\
\hline 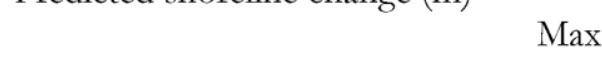 & -31 & 110 & -43 & 134 & -49 & 142 & -67 & 172 \\
\hline Mean & -10 & 19 & -14 & 28 & -19 & 36 & -24 & 44 \\
\hline Min & -0.4 & 0 & -1 & 0 & -1.4 & 0 & -2 & 0 \\
\hline $\mathrm{SD}$ & 10 & 32 & 14 & 40 & 18 & 47 & 22 & 53 \\
\hline \multicolumn{9}{|l|}{ Actual shoreline accretion (m) } \\
\hline (5) & 237 & 221 & 237 & 276 & 250 & 300 & - & - \\
\hline Mean & 30 & 25 & 27 & 32 & 32 & 33 & - & - \\
\hline Min & 0 & 0 & 0 & 0 & 0 & 0 & - & - \\
\hline $\mathrm{SD}$ & 56 & 53 & 56 & 64 & 59 & 79 & - & - \\
\hline \multicolumn{9}{|l|}{ Actual shoreline recession (m) } \\
\hline 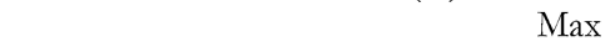 & -18 & 0 & -14 & -14 & -9 & -23 & - & - \\
\hline Mean & -6 & - & -5 & -14 & -5 & -11 & - & - \\
\hline Min & -1 & - & -1 & -14 & -1 & -5 & & \\
\hline 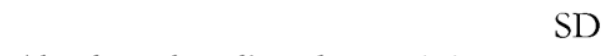 & 7 & - & 5 & - & 3 & 8 & - & - \\
\hline \multicolumn{9}{|l|}{ Absolute shoreline change $(\mathrm{m})$} \\
\hline 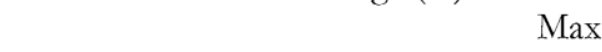 & 267 & 111 & 280 & 142 & 299 & 158 & - & - \\
\hline Mean & 35 & 15 & 43 & 26 & 44 & 26 & - & - \\
\hline Min & 0.3 & 0.2 & 0.2 & 1 & 0.2 & 2 & - & - \\
\hline $\mathrm{SD}$ & 60 & 25 & 64 & 29 & 71 & 35 & - & - \\
\hline
\end{tabular}

$* \mathrm{~N}=$ Northern coast, ${ }^{*} * \mathrm{~S}=$ Southern coast

Table 9. Percentage of errors between predicted and image-analyzed shoreline changes at the northern $(\mathrm{N})$ and southern (S) coasts of Pranburi Jetties (transects 95151).

\begin{tabular}{|c|c|c|c|c|c|c|}
\hline \multirow{2}{*}{$\begin{array}{l}\text { Percentage } \\
\text { of errors }\end{array}$} & \multicolumn{2}{|c|}{2009} & \multicolumn{2}{|c|}{2014} & \multicolumn{2}{|c|}{2018} \\
\hline & $\mathbf{N}$ & $\mathbf{S}$ & $\mathbf{N}$ & S & $\mathbf{N}$ & $\mathrm{S}$ \\
\hline Maximum & 13,005 & 655 & 939 & 1,145 & 1,283 & 1,372 \\
\hline Mean & 759 & 149 & 262 & 216 & 244 & 285 \\
\hline Minimum & 26 & 2 & 10 & 13 & 6 & 11 \\
\hline $\mathrm{SD}$ & 2,382 & 186 & 206 & 316 & 237 & 411 \\
\hline
\end{tabular}

\section{Discussion}

\subsection{Impact of Pranburi Jetty Project to Shoreline Change}

Based on the results from shoreline change analysis, the Pranburi Coast before the Pranburi Jetties construction was considered as a stable coast as the rate of shoreline change mostly less than $\pm 1 \mathrm{~m} / \mathrm{yr}$ except near the Pranburi River mouth (Z3 and Z4). The Z1, $\mathrm{Z} 2$, and Z3 littoral cells were separated by the natural headland (hills and mountains). Meanwhile, Z3 and Z4 could be combined as a littoral cell before the construction of the jetties. The high rate of shoreline accretion (up to $8.0 \mathrm{~m} / \mathrm{yr}$ ) occurred near the river mouth as a result of fluvial and coastal sediment processes. Riverine sediment was directly discharged from the Pranburi River, which is the major river of this coastal zone, and was deposited near the river mouth during the wet season (September-December). The sediment at the Pranburi River mouth was transported toward the north by the wave during the SW monsoon (April-September). Then, it transported back southward due to the wave-induced by the NE monsoon (October-January). Meanwhile, the longshore sediment transported along the coast came from the nonequilibrium coasts such as Leam Ket (in Thai, "Leam" means convex beach) and Had Pran Kiri (located at the mid of Z3 as shown in Fig. 3). As the alongshore sediment was transported in both northward and southward directions due to the influence of monsoons, the amount of longshore sediment transported southward should be relatively comparable to that transported northward. 
Marine Department reported that the suspended sediment discharge from the Pranburi River was about 2,000 $\mathrm{m}^{3} / \mathrm{yr}$, while the longshore sediment transported northward (S-N) and southward (N-S) were estimated as 74,750 and $63,794 \mathrm{~m}^{3} / \mathrm{yr}$, respectively [12]. Regarding the beach and sandspit formation observed from the aerial photographs between 1967-1994 (Fig. 7), longshore sediment transport was the major source of sediment deposition. It was the cause of shoaling at the river mouth. However, the formation of the beach and sandspit at the Pranburi River mouth indicated the higher N-S sediment transport than the S-N sediment transport as the land growth area in the north of river mouth (16.2 ha, $0.6 \mathrm{ha} / \mathrm{yr})$ was higher than that in the south (9.0 ha, $0.33 \mathrm{ha} / \mathrm{yr}$ ) as shown in Fig. 7. Because the NE monsoon induced the sediment transported southward, the northern portion of Z3 such as Khao Tao and Had Pran Khiri (Fig. 4a) were the potential sources for the longshore sediment in this littoral cell as about 30 percent of Z3 had experienced shoreline erosion before the construction of the Pranburi Jetties. Especially along the $2.4 \mathrm{~km}$ of Had Pran Khiri beach, the significant shoreline erosion (about $-0.5 \mathrm{~m} / \mathrm{yr}$ ) has been observed. Before the jetties construction, the average shoreline retreat rate along the Z3 seemed to be low (less than $-1 \mathrm{~m} / \mathrm{yr}$ ) because some sediment could return during the SW monsoon season. Similarly, the southern portion of the littoral cell (Z4) was the potential source of longshore sediment during the SW monsoon season. With the convex coastline shape and the highest rate of shoreline retreat in Z4, Leam Ket and Had Naresuan beaches (Fig. 4a) were the primary sources of the longshore sediment of this littoral cell. On the one hand, the sediment eroded from Leam Ket transported southward during the NE monsoon and then deposited at the end of the bay. On the other hand, the sediment transported northward during the SW monsoon and sank at the Pranburi River mouth.

After the completion of the Pranburi Jetties in 1999, the Z3 and Z4 littoral cells were separated by the jetties. Consequently, the jetties performed as a new headland for the Z3 and Z4. The N-S longshore sediment transport during the NE monsoon has been trapped by the north jetty resulting in land growth during $1998-2018$ of 10 ha $(0.5 \mathrm{ha} / \mathrm{yr})$ instead of land loss of 6.5 ha as predicted (Table 8 ). The SW monsoon induced S-N sediment transport, which was trapped by the south jetty, causing the land deposition at the south jetty of 5.9 ha (0.3 ha/yr), as shown in Fig. 7.

As mention above, the north jetty has trapped the $\mathrm{N}-\mathrm{S}$ sediment transport resulting in significant shoreline accretion instead of shoreline recession as predicted by the numerical model. Even though three breakwaters were built right after the jetty construction, they were not the primary cause of a significant shoreline accretion in this portion as the shape of the shoreline followed the equilibrium shape bay due to the jetty instead of equilibrium shoreline due to the breakwater. Moreover, because of the more considerable land growth on the northern coast of the Pranburi River, the sediment supply from the north was greater than the estimated of longshore sediment due to the high wave energy dominated by the NE monsoon. Therefore, the construction of three breakwaters probably was unnecessary because the jetty can trap the whole longshore sediment from the north resulting in land growth at the north of the jetties anyway.
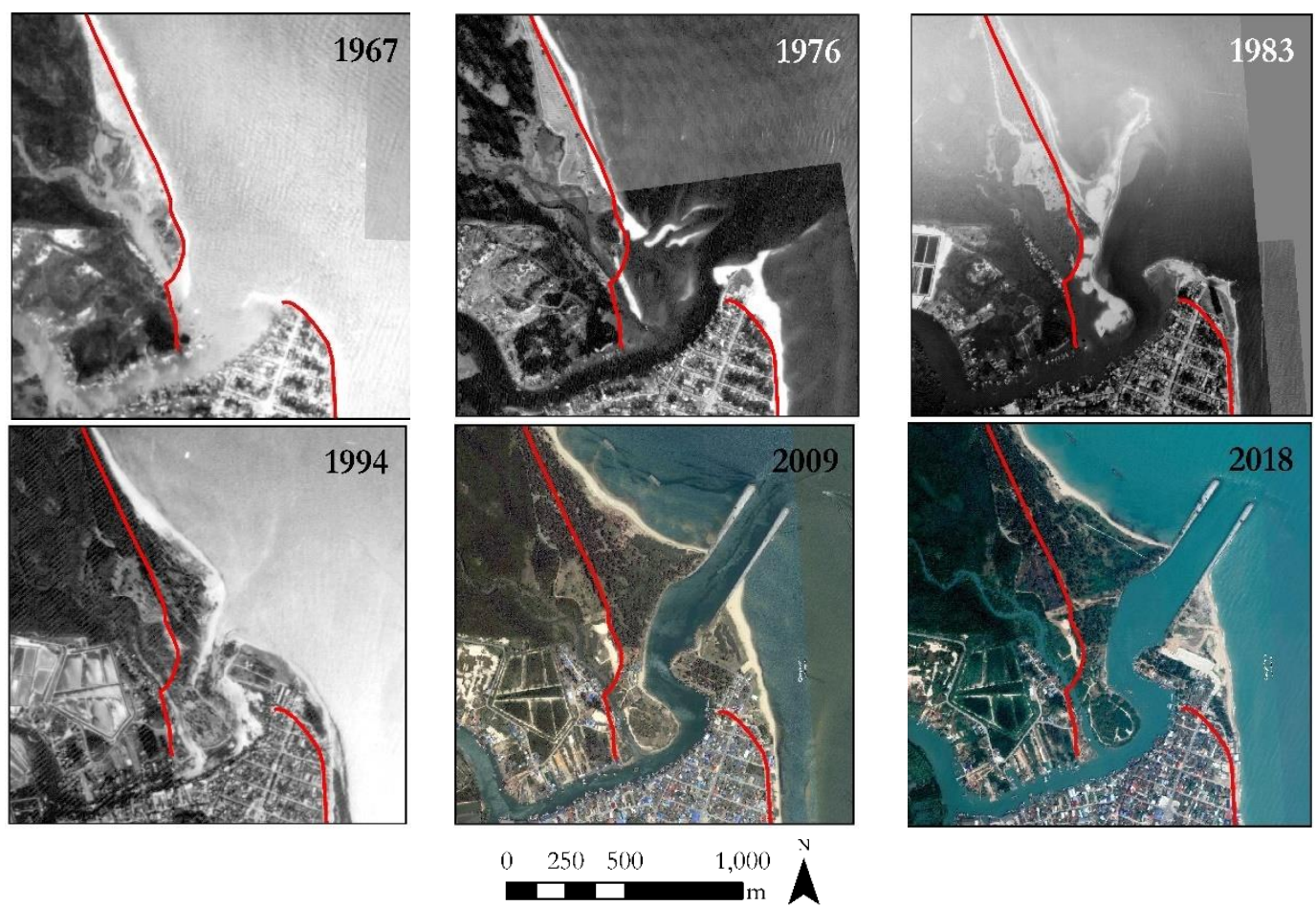

Fig. 7. Evolution of shoreline change at Pranburi River mouth (the red line represented the shoreline in 1967). 
With the lengths of the south and north jetty of $800 \mathrm{~m}$ and $860 \mathrm{~m}$, respectively, the jetty did not only block the fluvial sediment from the Pranburi river supplying to the Z3 and Z4 but also prevented seasonal longshore sediment to move back to the source areas. Consequently, it had caused the sediment deficit at the sediment supply source of Z3 and Z4. Even though the results of the horizontal shoreline change analysis did not show significant shoreline retreat at Had Pran Khiri (Z3's sediment source) after the construction of the jetties, the length of private seawall along Had Pran Khiri shoreline extended from $300 \mathrm{~m}$ in 1999 [19] to $900 \mathrm{~m}$ in 2018 (Fig. 1 and Fig. 7). Moreover, regarding the field survey, the severe vertical shoreline erosion was observed, as shown in Fig. 8a-b.
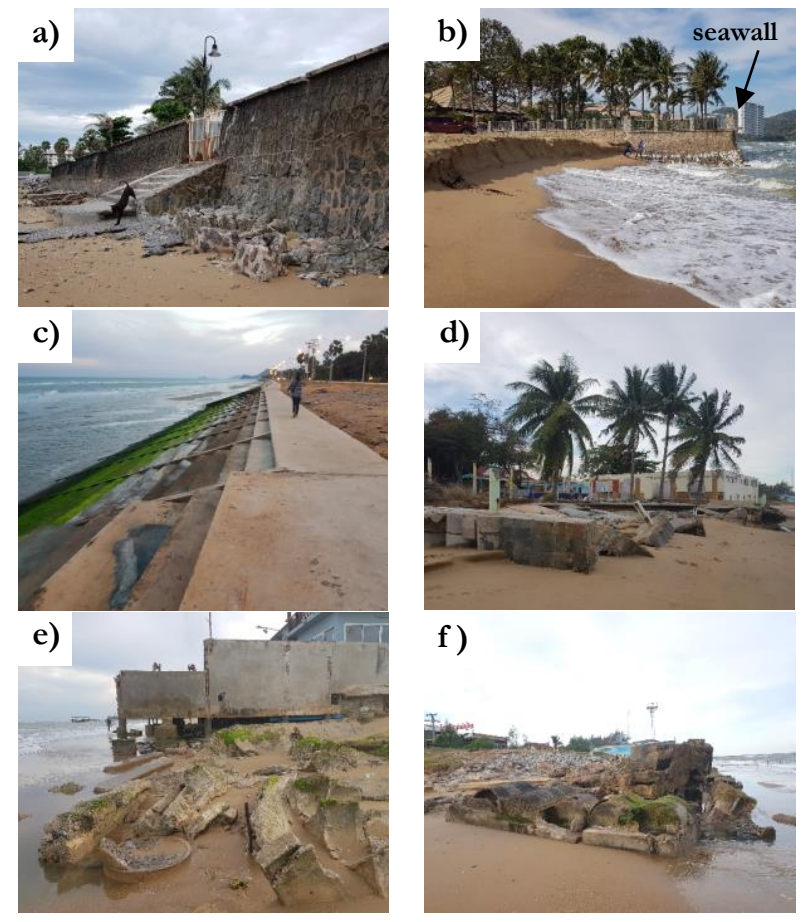

Fig. 8. a) Seawall at Had Pran Khiri (Z3), b) Shoreline erosion in Z3, c) Seawall along with Lame Ket (Z4), and d)-f) Property damages between transect $134-140$ (Z4).

Likewise, the results of shoreline analysis indicate that the shoreline along Laem Ket, which was the sediment source of Z4, migrated seaward up to present. However, by considering the shoreline position of each consecutive year of available aerial photographs (Fig. 4), it was found that the shoreline had continuously retreated until 2009. During 2009-2015, land reclamation and seawall construction (Fig. 8c) were applied along $3.4 \mathrm{~km}$ of Leam Ket to mitigate the shoreline recession problem. Because the seawall was used to stabilize the shoreline, then the Laem Ket beach could not supply the sand sediment to the upcoast and downcoast as previously. The adjacent unprotected area, Ban Pak Nam Pran (transects 134-140), seemed to be a new sediment source of $\mathrm{Z} 4$ as the significant of shoreline retreat occurred in this area after 2009. Based on field observation, severe coastal erosion was found in this area, as illustrated in Fig. 8 d-f.

Along with Z1, the significant shoreline changes, especially shoreline accretion, were found only at the northmost and southmost of the littoral cell after the post-construction of the Pranburi Jetties period. The construction of two short jetties caused the sediment deposition at both locations at Khao Takiap channel and Khao Tao (Fig. 1). A low degree of erosion was found near the Khao Tao Jetty as a result of shoreline adjustment to reach a new equilibrium. Meanwhile, the Z2 coastline had a slight change in the rate of shoreline change $( \pm 0.1 \mathrm{~m} / \mathrm{yr})$. It can be implied that the construction of Pranburi Jetties had an insignificant impact on the shorelines along Z1 and Z2 because natural headlands separated them.

\subsection{Effectiveness of Shoreline Change Prediction}

Regarding the difference between the imageanalyzed shorelines and predicted shorelines by the One-Line model (Table 8), the uncertainty (percentage of absolute errors) of the shoreline change prediction along the transects 95-151 due to the construction of Pranburi Jetties varied between 2 and 13,000 percent (Table 9). The maximum and substantial degree of errors were mainly found at the northern coast of the jetty as the deposition took place after the jetty construction instead of erosion as predicted. On the southern coast of the jetties, even though the trend of image-analyzed shoreline response agreed with the prediction, the magnitude, and shape of shoreline change were still quite different (Fig. 2).

The misprediction possibly caused by several reasons. Wave data, for example, could be one of the significant factors as the wave characteristics (wave height, wave period, and wave direction) play a considerable role in dominating the sediment transport in the coastal zone. According to the coastal processes study of the Pranburi Jetties project [12], long-term wave data in the study area was not available. Wave hindcasting using 12-years wind data from the meteorological station (overland wind) was used for estimating wave characteristics in the study area. Wave data observed by an oceanographic buoy (THAI-7) in 1994 were used to calibrate the wave hindcasting model. The results from wave hindcasting indicated that the estimated significant wave height and wave period in deep water were $3.75 \mathrm{~m}$ and 4-9 seconds, respectively (Table 1). However, the results from wave hindcasting software suggested that wave direction was mainly from E-SSE. Therefore, the model suggested the construction of the jetties would cause the deposition on the southern coast and the erosion on the northern coast.

Typically, when waves approach the shore from different quadrants, they produce day-to-day and seasonal reversals in sediment transport direction [33]. Therefore, errors in wave magnitude and direction can cause a significant misestimation of sediment transport 
rate and direction. In the Pranburi Jetties project, as the predicted wave direction mainly came from the south, the predicted sediment then mainly transported northward. However, sea waves are primarily generated by wind, so the direction of overwater wind typically can be used to estimate the wave direction when the wave direction data are not available. For Pranburi Coast, the wind prevailing during the NE monsoon typically generates the waves traveling to the south direction resulting in N-S sediment transport. Meanwhile, the SW monsoon wind produces the waves propagating to the north, causing the S-N sediment transport. Based on the results from wave statistic analysis, it was found that higher waves, which had higher wave energy, mainly occurred during the NE monsoon. Therefore, the longshore sediment transport in the N-S direction was potentially more considerable than that in the S-N direction. This observed wave information supported the more significant land growth found on the northern coast compared to the southern coast. Therefore, wave characteristics generated from wind data, especially from overland wind data, may be significantly different from the actual waves approaching the Pranburi Coast. Consequently, it produced a significant uncertainty in shoreline prediction for the Pranburi Jetties project.

Based on this study, the misestimation of the wave direction had caused significant misprediction in shoreline change on the north coast of the jetties with a maximum error of $300 \mathrm{~m}$. On the southern coast, the accretion of the shoreline has occurred in the vicinity of the south jetty as expected, the shape of image-analyzed shoreline changes was different from the prediction. The maximum error of prediction for the southern coast was $158 \mathrm{~m}$ (in 2018).

Another major cause of shoreline prediction error was the sediment data. Regarding Coastal Engineering Manual [36], it was documented that sediment grain size correlated with the longshore sediment transport rate. As longshore sediment transport rate in the study area was calculated using the formulae proposed in Shore Protection Manual [37] (Table 1), the sediment transport rate was calculated based on the influence of waves only. Moreover, only sediment data sampling at the river mouth, in which the average sediment grain size varied between $0.0078-1.0 \mathrm{~mm}$ were used in shoreline change study. However, average $d_{50}$ of the beach material observed along the Z3 and Z4 littoral zones where the jetties are located ranged from 0.29 to $0.47 \mathrm{~mm}$. Therefore, inaccurate sediment data may also be responsible for the misprediction of shoreline change using the One-Line model in the Pranburi Jetties Project.

Because a significant shoreline recession at the north of the jetty was predicted, the construction of three detached breakwaters within a year after the completion of the jetties was suggested to prevent coastal erosion. Three detached breakwaters with the cost of about 100,000 USD (in 1998) [12] were built offshore, as shown in Fig. 3b. As mention above, the shoreline has significantly advanced seaward instead of moving landward. In contrast, the shoreline accretion at the southern coast was predicted, and the shore would develop rapidly and would outweigh shoreline erosion along Laem Ket beach since 2009. However, severe shoreline retreat still took place along Laem Ket between transects 136-140. As the shoreline protection measure has not been planned during the study processes, the erosion has caused the land losses of about 0.8 ha.

Regarding the results from this study, using oceanographic data observed in the study area may improve the accuracy of shoreline change prediction using a numerical model. Long-term wave observation is suggested to use instead of wave hindcasting to improve the effectiveness of the sediment transport prediction. Moreover, sediment transport measurement is recommended to include in coastal processes study to reduce the errors of shoreline change prediction. Even though field observation may cause more budget for project planning, it may significantly reduce costs for unnecessary structures and adverse effects due to the misplanning.

\section{Conclusion}

According to the results of historical shoreline change and sediment characteristics along the study area, the Pranburi Jetties project had influenced to shoreline change between Kho Tao and Kho Kalok (transect 95-210). Before the Pranburi Jetties project construction (1967-1994), the formation of sandspit had occurred at the Pranburi River mouth, due to longshore sediment transport in the north-south direction. The maximum rate of shoreline changes on the northern and southern coasts was $8.0 \mathrm{~m} / \mathrm{yr}(216 \mathrm{~m})$ and $6.7 \mathrm{~m} / \mathrm{yr}(181 \mathrm{~m})$, respectively. Moreover, the north coast had more land growth (16.2 ha) than the southern coast $(9 \mathrm{ha})$. It indicated that longshore sediment transport had more sediment moved southward than northward. During the past two decades after the completion of the Pranburi Jetties project, longshore sediment was tapped by the jetties resulting in significant shoreline accretion adjacent to the jetties. The maximum rate of shoreline change was $12.5 \mathrm{~m} / \mathrm{yr}$ $(250 \mathrm{~m})$ at the northern coast and $15 \mathrm{~m} / \mathrm{yr}(300 \mathrm{~m})$ at the southern coast. In the project planning stage, the results from the One-Line model suggested that the construction of the jetties would cause shoreline recession at the northern coast of the jetty but accretion at the southern coast. However, the results from this study indicated that the image-analyzed shoreline response disagreed with the simulation, especially on the northern coast of the jetty. The errors of shoreline prediction varied between 2 and 13,000 percent. Misprediction by One-Line model strongly seems relating to the use of estimated wave characteristics and sediment data as the model input. Misprediction had caused unnecessary construction of three detached 
breakwaters on the northern coast of the jetty. Moreover, it caused misplanning on preparation for adverse effects due to the project. In order to improve the accuracy of shoreline prediction using a numerical model, observed wave and sediment data are recommended to be used as the input data instead of estimated or generated data.

\section{Acknowledgment}

This research was financially supported by Research Assistant Scholarship (GCUGE17) and partially supported by the 90 th Anniversary of Chulalongkorn University Fund (Ratchadaphiseksomphot Endowment Fund), Graduate School, Chulalongkorn University. Moreover, facility things were supported by WISE Research Unit, Water Resources Engineering Department, Chulalongkorn University. The authors also thank the editor and anonymous reviewers for their valuable comments and suggestions to improve the quality of the manuscript.

\section{References}

[1] D. Reeve, A. Chadwick, and C. Fleming, "Conceptual and detailed design," in Coastal Engineering: Processes, Theory and Design Practice. CRC Press, 2004, ch. 9, pp. 132.

[2] R. M. Sorensen, "Coastal zone processes," in Basic Coastal Engineering. Springer, 2006, ch. 8, pp. 265.

[3] K. R. Bodge, "Design aspects of groins and jetties," in Advance in Coastal Structure Design. ASCE, 2003, ch. 9, pp. 181-199.

[4] R. G. Dean, R. Chen, and, A. E. Browder, "Full scale monitoring study of a submerged breakwater, Palm Beach, Florida, USA," Coast. Eng., vol. 29, no. 3, pp. 291-315, 1997.

[5] J. Ahrens, and J. Cox, "Design and performance of reef breakwaters," J. Coast Res., pp. 61-75, 1990.

[6] C. Zimmermann, R. G. Dean, V. Penchev, and H. J. Verhagen, "Environmentally friendly coastal protection," in Proceedings of the NATO Advanced Research Workshop on Environmentally Friendly Coastal Protection Structures, Varna, Bulgaria, 25-27 May 2004, Springer Science \& Business Media, 2005.

[7] A. S. Islam, S. K. Bala, M. A. Hussain, M. A. Hossain, and M. M. Rahman, "Performance of coastal structures during Cyclone Sidr," Nat Hazards Rev., vol. 12, no. 3, pp. 111-116, 2010.

[8] U.S. Army Corps of Engineers, "Monitoring, maintenance, and repair of coastal projects," Rep. EM1110- 2-1100 (part VI), 2011.

[9] Z. Huang, Y. Li, and Y. Liu, "Hydraulic performance and wave loadings of perforated/slotted coastal structures: A review," Ocean Eng., vol. 38, no. 10, pp. 1031-1053, 2011.

[10] C. S. Hardaway Jr. and J. R. Gunn, "Design and performance of headland bays in Chesapeake Bay, USA," Coast. Eng., vol. 57, no. 2, pp. 203-212, 2013.
[11] B. Bidorn and C. Rukvichai, "Impacts of coastal development on the shoreline change of the Eastern Gulf of Thailand," IOP Conf. Ser.: Earth Environ. Sci, vol. 171, no. 1, p. 012007, 2018.

[12] Marine Department, "Report of feasibility study of the economy, engineering, and environmental for construction of jetty at Pranburi channel, Prachuap Khiri Khan Province," (in Thai) 1996.

[13] H. Hanson, "Genesis-A generalized shoreline change numerical model," J. Coast Res., vol. 5, no. 1, pp. 1-27, 1989.

[14] U.S. Army Corps of Engineers, "Shoreline change modeling using One-Line Models: General model comparison and literature review," Rep. ERDC/CHL CHETN-II-55, 2013.

[15] Department of Mineral Resources, "Report of coastal erosion survey and study at Gulf of Thailand and Andaman (Surat Thani, Nakorn Sri Thammarat, and Songkhla)," (in Thai) 2006.

[16] Marine Department, "Final report of master plan and basic design for solving coastal erosion at the Lower Gulf of Thailand from Laem Talumphuk to Songkhla lake," (in Thai) 2013.

[17] C. Saengsupavanich, "Willingness to restore jettycreated erosion at a famous tourism beach," Ocean. Coast. Manag., vol. 178, p.104817, 2019.

[18] Department of Mineral Resources, "Geology," (in Thai) in Geological and Mineral Resources Management at Prachuap Khiri Khan Province, Bangkok, Thailand, 2008, ch. 3, pp. 14-15.

[19] Royal Irrigation Department, "The relation between suspended sediment and drainage area in 25 river basins," (in Thai) 2012.

[20] Chulalongkorn University, "The southern short cut motorway project (Samut Sakorn-Laem Pak Bia-Cha Am)," (in Thai) Bangkok, 2007.

[21] Ministry of Natural Resources and Environment, "Master plan for coastal erosion management from Phetchaburi River-mouth, Phetchaburi Province to Pranburi River-mouth, Prachuap Khiri Khan Province," (in Thai) 2003.

[22] X. Zhang, D. Pan, J. Chen, J. Zhao, Q. Zhu, and H. Huang, "Evaluation of coastline changes under human intervention using multi-temporal highresolution images: A case study of the Zhoushan Islands, China," Remote Sens., vol. 6, pp. 9930-9950, 2014.

[23] W. C. O'Reilly, C. B. Olfe, J. Thomas, R. J. Seymour, and R. T. Guza, "The California coastal wave monitoring and prediction system," Coast Eng. J., vol. 116, pp. 118-132, 2016.

[24] B. Bidorn, P. Kongsawadworakul, N. Phanomphongphaisarn, and C. Rukvichai, "Evolution of mangrove muddy coast in the Western Coast of the Upper Gulf of Thailand over the past six decades," in ICEC, August 20-23, 2018, Caen, France, 2018.

[25] E. Theiler, "Digital shoreline analysis system (DSAS) version 4.0-An ArcGIS extension for 
calculating shoreline change," U.S. Geological Survey, Rep. Open-File Report, 2011.

[26] M. Ford, "Shoreline changes interpreted from multi-temporal aerial photographs and high resolution satellite images: Wotje Atoll, Marshall Islands," Remote Sens. Environ., vol. 135, pp. 130140, 2013.

[27] R. S. Kankara, S. C. Selvan, V. J. Markose, B. Rajan, and S. Arockiaraj, "Estimation of long and short term shoreline changes along Andhra Pradesh coast using Remote Sensing and GIS Techniques," Procedia Eng., vol. 116, pp. 855-862, 2015.

[28] S. C. Selvan, R. S. Kankara, V. J. Markose, B. Rajan, and K. Prabhu, "Shoreline change and impacts of coastal protection structures on Puducherry, SE coast of India," Nat Hazards., vol. 83, pp. 293-308, 2016.

[29] G. Qiao, H. Mi, W. Wang, X. Tong, Z. Li, Tan Li, S. Liu, and Y. Hong, "55-year (1960-2015) spatiotemporal shoreline change analysis using historical DISP and Landsat time series data in Shanghai," Int J Appl Earth Obs Geoinformation, vol. 68, pp. 238-251, 2018.

[30] C. Martínez, M. C. Lopez, P. Winckler, H. Hidalgo, E. Godoy, and R. Agredano, "Coastal erosion in central Chile: A new hazard?," Ocean Coast Manage, vol. 156, pp. 141-155, 2018.

[31] L. D. Río, F. J. Gracia, and J. Benavente, "Shoreline change patterns in sandy coasts. A case study in SW Spain," Geomorphology, vol. 196, pp. 252-266, 2013.

[32] U.S. Army Corps of Engineers, "Coastal sediment properties," the Coastal Engineering Manual, Rep. EM 1110-2-1100, 2002.

[33] U.S. Army Engineer Waterways Experiment Station, "The unified soil classification system," Washington, D.C., Rep. 3-357, 1960.

[34] C. K. Wentworth, "A scale of grade and class terms for clastic sediments," J. Geol., vol. 30, pp. 377-392, 1922.

[35] R. L. Folk and W. C. Ward, "Brazos river bar: A study in the significance of grain size parameters," J. Sediment. Petrol., vol. 27, no. 1, pp. 3-26, 1957.

[36] U.S. Army Corps of Engineers, "Coastal engineering manual," Rep. EM1110-2-1100, 2002.

[37] CERC, Shore Protection Manual. Washington: CERC Dept. of the Army, U.S. Army Corps of Engineers, Washington, 1984, vol. 2. 


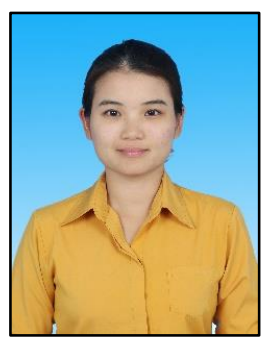

Nathamon Phanomphongphaisarn was born in Bangkok, Thailand in 1989. She received the B.S. degree in Department of Geology, Faculty of Science, from Chulalongkorn University, Thailand, in 2012.

From 2012 - present, she work at Electricity Generating Authority of Thailand (EGAT) as a Geologist. She has studies M.S. degree in Department of Water Resources Engineering, Faculty of Engineering, Chulalongkorn University, Thailand since 2016. Her research interests in coastlal engineering and sedimentation. She is a researcher in WISE Resarch Unit of Chulalongkorn University since 2018.

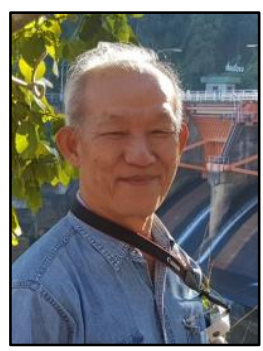

Chaipant Rukvichai was born in Pitsanulok, Thailand in 1949. He recieved the B.Eng.(Civil Engineering) from Chulalongkorn University, Bangkok in 1971 and the MSCE and Ph.D. in Civil Engineering from Purdue University, USA in 1978.

He worked in the Dam Design Section at the Royal Irrigation Department during 1978-1979. He was an associate professor of the Department of Civil Engineering, Chulalongkorn University since 1979-1992, and the Department of Water Resources Engineering, Chulalongkorn University since 1992 till his retirement in 2010.

His work experiences and researches included the planning and design of dams and water resources development projects, environmental impact investigations, water management, river hydraulics, and coastal erosion and protection.

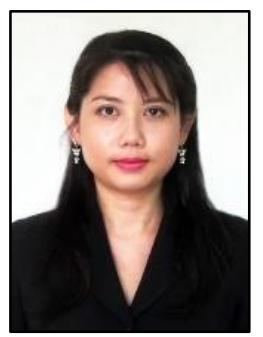

Butsawan Bidorn was born in Ban Prik Village, Nakhon Nayok Province, Thailand in 1972. She received the B.Eng and M.Eng degrees in Water Resources Engineering from Kasetsart University in 1995 and Chulalongkorn University in 1999, respectively. In 2016, she received a Ph.D. degree in Geology from Florida State University, Florida, USA.

Since 2000, she has been a lecturer at the Department of Water Resources Engineering, Chulalongkorn University, Bangkok, Thailand. She is the author of a book and thirty research articles in the field of water resources engineering. Her research interests include hydraulics, coastal processes, fluvial and coastal sediment processes, marine geology, coastal and river engineering, and interdisciplinary researches. At present, she is the head of the WISE Research Unit, the first interdisciplinary research unit of Chulalongkorn University. 